Pereira, D., Flores, A., \& Niklasson, L. (2016). Assessment revisited: a review of research in Assessment and Evaluation in Higher Education. Assessment \& Evaluation

in Higher Education, 41 (7), pp. 1008-1032

\title{
Assessment Revisited: a review of research in Assessment and Evaluation in Higher Education
}

\begin{abstract}
A review of articles published in Assessment and Evaluation in Higher Education journal, over the last 8 years, (2006-2013) on assessment in Higher Education, since the introduction of the Bologna Process, is the subject of the paper. The first part discusses the key issue of assessment in higher education and the method used for selecting articles. The second part presents results according to the main emerging themes arising from data analysis: assessment methods; modes of assessment; and assessment related to a given teaching and learning method. The paper concludes that the foci of the studies are aligned with assessment practices other than the written test, in accordance with a learner-oriented perspective. Although the implementation of the Bologna Process has had different kinds of impact in different European countries, the review has shown that the use and effects of a diversity of assessment methods in Higher Education have been investigated, particularly those pointing to the so-called alternative methods. Implications of the findings are discussed.
\end{abstract}

Keywords: Bologna process, Assessment, Higher Education, Teaching and Learning Process, Learnercentred Assessment

\section{Introduction}

Assessment process in higher education has changed over the last few years. In addition to the Bologna Process (Bologna Declaration 1999), that provided significant changes with regard to the process of teaching, learning and assessment, existing literature also suggests the existence of an assessment approach more focused on student and learning (Dochy and McDowell 1997, Black and William 1998; Webber 2012).

The interest related to students and their learning is also shown in a variety of studies which highlight how assessment and learning can be connected. Assessment has significant effects on student learning, (Gibbs 1999; Scouller 1998) as assessment and learning are closely related (Scouller 1998; Light and Cox 2003). The teaching methods must be aligned with assessment methods and learning goals for teaching effectiveness 
to be enhanced (Biggs 2003). Assessment practices adopted have an important role in the quality of learning (Atkins 1995; Fernandes, Flores, and Lima 2012; Flores et al. 2014) and influence the ways in which students perceive learning (Brown and Knight 1994; Drew 2001). The influence of assessment on learning, either negatively or positively, might be seen as an incentive for study and improved performance (Watering, Gijbels and Dochy 2008; Biggs 2003; Brown and Knight 1994; Brown, Bull and Pendlebury 1997; Boud and Falchikov 2007). Assessment practices based on a learner-centred assessment enhance the active involvement of the students, produce feedback, enable collaboration between students and faculty and allow teachers to realise how learning is occurring (Webber 2012). Such practices prepare students for professional life promoting problem solving and skills development in real-life contexts (Dochy, Segers and Sluijsmans 1999). During the past eight years, Assessment and Evaluation in Higher Education published a large number of articles that reported research on assessment in higher education. The studies were carried out in different countries and different methods were used. This paper summarizes and critically discusses a selection of empirical studies focusing on assessment in Higher Education, particularly on how different practices of assessment have been scrutinised in research, since the implementation of the Bologna Process in Europe. Thus, the overarching questions of this paper are:

- Which is the focus of the studies on assessment in higher education after the Bologna Process?

- What kind of themes emerge from them?

- What do we know about assessment in higher education from papers published in AEHE?

- What are the questions that remain answered?

\section{The Bologna Process}

The general assumption of the Bologna Process was the creation of a European Higher Education Area enabling students of any institution to start, continue or complete their education and get a degree in any EU Member State University through the European Credit Transfer System (ECTS) (Bologna Declaration 1999). In most European countries, this has implied changes in curriculum regarding teaching, learning and 
assessment (Flores et al. 2014; Flores and Veiga Simão 2007) in so far as students are seen as active learners (Flores and Veiga Simão 2007; Simão, Santos, and Costa 2003). The European Association for Quality Assurance in Higher Education states that assessment requires students to be evaluated through explicit assessment criteria for marking, therefore the procedures have to be adequate to the formative, summative or diagnostic assessment purposes, and the assessment strategy should be clear and communicated to students. In addition, assessment is an indicator of teaching and learning effectiveness and its outcomes impact on the future careers of the students (EAQAHE 2009).

In addition to the Bologna Process, the Leuven/Louvain-la-Neuve Communiqué (2009) refers to the importance of a student-centred learning approach that helps students develop competences needed in real life. This implies a student-centred curriculum reform, based on new approaches to teaching and learning along with effective support. Later, in 2012, the Bucharest Communique further reaffirmed the importance of continuously promoting student-centred learning encouraging the use of innovative methods enabling students to participate in their own learning developing critical thinking (Bucharest Communiqué 2012).

\section{Assessment in Higher Education}

The assessment methods traditionally used in higher education are the examinations and written tests (Perrenoud 1999, Pereira and Flores 2012; Scouller 1998). However, these methods do not inform how learning occurred as they mainly promote a hierarchy of grades (Perrenoud 1999). A brief review of the literature about assessment methods reveals that tests with Multiple Choice Questions (MCQ) bring some issues (Scouller and Prosser 1994) encouraging surface rather than deep learning (Ramsden 1988; Tang 1992; Struyven, Dochy and Janssens 2005) and assessing low levels of cognitive processing (Scouller 1998). Also, researchers found that students with poor learning skills and low confidence prefer MCQ tests rather than essays (Birenbaum and Feldman 1998). Earlier empirical work (Sambell, McDowell and Brown 1997) shows that students have a negative opinion about traditional assessment methods (namely written tests and exams), considering that they affect negatively the learning process. In contrast, the same students state that new and alternative assessment methods enable a better quality of learning promoting understanding rather than memorisation. For 
example, Segers and Dochy (2001) demonstrate that students have positive perceptions about the use of self and peer assessment in a problem-based learning environment in so far as they stimulate deep learning and critical thinking.

The so-called learner-centred methods foster the development of autonomy, sense of responsibility, and reflection (Sambell and McDoweel 1997) and influence the ways in which students look at their own learning (Sluijsmans, Dochy and Moerkerke 1999). However, the non-traditional methods do not always change the perceptions of students and do not always lead to deep learning (Segers, Gijbels and Thurlings 2008). In fact, students' approaches to learning (Marton and Saljo 1997) may be influenced by the assessment methods and assessment tasks (Struyven, Dochy and Janssens 2005). Thus, a wide variety of methods should be used (Wen and Tsai 2006; Brown, Race and Rust 1995) and teachers should be designers of the assessment process avoiding the exclusive use of traditional assessment (Boud 1995). This is because the focus of higher education is also developing both technical and soft skills in order for students to be successful in their future careers (Dochy, Segers and Sluijsmans 1999). Learner-centred methods (Webber 2012) enhance the development of the skills needed for real life, because the purpose of assessment is to ensure that the success criteria of education and of the training process is the same as used in practice (Segers and Dochy 2001).

Learner-centred practices such as self and peer-assessment enhance students' autonomy, self-confidence and reflection (Dochy, Segers and Sluijsmans 1999) allowing the development of skills (Sambell and McDowell 1997) and promoting deep learning (Brew, Riley and Walta 2009). Methods such as problem-based and case-based learning promote the development of professional skills and learning in real life contexts (Dochy, Segers and Sluijsmans 1999). These methods are considered as new or alternative methods for assessing students in Higher Education. However, more needs to be known about the effectiveness and relevance of these methods in different contexts and programmes in higher education. Thus, it is important to learn more about empirical research on assessment in higher education, especially after the implementation of the Bologna process.

\section{Method}

As a first step, the journal Assessment and Evaluation in Higher Education was chosen for a review of scientific production about assessment in Higher Education. This choice 
was made because the main focus of the journal is assessment and evaluation in higher education and preliminary literature review has shown that there were many studies on this topic. This journal was then considered relevant to find key papers about the assessment methods in higher education due to its specific aims and scope. However, other research published elsewhere (namely in journals related to higher education but not focusing on assessment and evaluation) was also considered in order to frame the topic of this paper.

As a second step, articles from 2006 until 2013 were chosen as they are subsequent to the implementation of the Bologna Process in European Universities. This choice was made because from 2006 onwards articles more directly related to the implementation of the Bologna Process have begun to be published. As a third step, a choice of keywords was made in order to use them in the search: "assessment methods", "teaching" and "learning". These keywords were chosen because the purpose of this article is to find out what kinds of themes and main conclusions emerge from recent research in this field. As the assessment is directly related to teaching and learning it seemed appropriate to include also these keywords in the search.

From the first search 64 articles were identified. After the examination of the abstracts and in some cases the complete article, 7 articles were excluded since they were not in the focus of our study, covering topics such as learning environment, learning communities, educational choices and conceptions of good teaching, thus, not directly related to assessment. A choice was made to select only empirical studies and not, for example, reflections and reviews of the literature. As a consequence, 57 articles drawn from empirical studies were selected. However, as one of the goals of this paper is to identify what is known about assessment in higher education, after the implementation of the Bologna process, 30 articles were selected (see table 1) according to the keywords, the descriptors and the context (since the remaining 27 articles were from non-European countries). The 27 articles excluded came from different countries such as Australia, United States of America, Hong Kong, South Africa, Canada, Lebanon, Korea, Singapore, Iran, Israel, China and Trinidad and Tobago. Articles in nonEuropean countries had different foci of study such as assessment methods, teaching effectiveness, portfolio assessment and formative and summative assessment. 
Content analysis was used to identify the emerging categories in order to describe, in a systematic and articulated way, the meaning of the data collected (Schreier 2012). The 30 articles were analysed concerning (1) aims of the study, (2) participants, (3) method, (4) main results, and (5) conclusions. After reading all the abstracts and the articles a categorisation was carried out resulting in the following emerging themes: i) assessment methods; ii) modes of assessment and iii) assessment related to a given teaching and learning method.

\section{Findings}

\subsection{Assessment Methods}

In this section studies focusing on different issues related to assessment methods used in higher education are analysed.

Table 2 near here

\subsubsection{Aim of the studies}

The papers listed in table 2 have similar purposes regarding the assessment methods in higher education. Some studies focus on the comparison of assessment methods (Tian 2007; Gleaves, Walker and Grey 2007; Huxham, Campbell and Westwood 2012) and on approaches and perceptions of assessment methods (Brinke, Sluijsmans and Jochems 2010; Turner et al. 2013) by both students and teachers. Other studies aimed at getting to know the nature of a given assessment method (Schaaf and Stokking 2008), its characterisation (Dysthe and Engelsen 2011) and its validity (Tummons 2010). Almond (2009) also sought to know the effects of group summative assessment on marks in comparison with individual assessments. The key feature of the remaining studies is the impact of assessment methods on students' learning process (Kuisma 2007) and students' performance in relation to a given assessment method (Betts et al. 2009).

\subsubsection{Methods}


Different research methods were used in the studies listed above. The questionnaire and the interviews were the most used methods for data collection purposes. Assessment methods were also used for data collection from the digital diaries to portfolios, group project, essays and multiple choice examinations. In the eleven studies listed above more students than teachers participated. Seven studies were conducted with students, three with teachers and one with both students and teachers.

\subsubsection{Key issues arising from the studies}

The results of the studies concerning a comparison of assessment methods reveal higher efficacy of some methods in detriment to others. Tian (2007) compared formal examinations and coursework in relation to approaches to learning. The author concluded that the approaches to learning are related to the assessment of learning outcomes. When students are assessed through assignment essay, deep learning approaches associated with good learning outcomes are identified. When students are assessed through formal examinations poor learning outcomes are highlighted. The author found that the assignment essay is a good assessment method in contrast to formal examinations. Gleaves, Walker and Grey (2007) compared digital diaries and paper diaries for students' assessment and learning. The authors found that the students consider both forms of diary acceptable and convenient. Digital diaries were used more frequently; however the entries were often incomplete. On the other hand, the students made fewer entries in paper diaries but these entries were longer and more discursive. Students who preferred the paper diaries engaged more in reflexive criticism. Huxham, Campbell and Westwood (2012) also compared oral and written examinations regarding students' performance and whether these methods were inclusive. The authors found that students performed better in oral than in written tests. However, there was evidence that oral assessments provoke more anxiety than written ones. Oral assessments were found to be more inclusive than written ones helping students to find a professional identity. The perceptions of the students' regarding oral examinations were the focus of Turner's et al. (2013) study. The authors suggested that oral presentations were seen as authentic learning context, although there were anxieties associated with these methods. Students felt there was a constructive alignment encouraging them to develop a professional identity. In relation to approaches of a given assessment method, Brinke, Sluijsmans and Jochems (2010) wanted to know the fairness, usability and relevance of 
portfolio assessment. The authors concluded that teachers considered portfolio assessment to be fair, useful and relevant. However, in some cases, the assessors' approaches to portfolio assessment differed. The rating criteria to assess the portfolio were interpreted differently by teachers. The authors also conclude that teachers detected lack of some skills such as written skills and thereafter asked the students additional assessments to overcome these shortcomings.

The study by Schaaf and Stokking (2008) concludes that developing a valid portfolio design is a complex and interactive process. Tummons (2010) also found that the ways in which portfolios are assessed can bring complexities and contradictions. The validity of portfolio-based assessment admits that portfolio is a reflection of the professional working practices and represents the engagement with learning.

However, Dysthe and Engelsen (2011) consider that existing differences between disciplines, policy decisions and pedagogical practices may influence the use of portfolio in higher education. In this regard, Kuisma (2007) found that portfolio assessment allows the students to produce a great amount of items and reflect what they had learnt during the learning process. Nevertheless, the students also admit that portfolio is a very time consuming process. Regarding group summative assessment Almond (2009) reveals that students who performed examinations with a peer evidence higher levels of motivation than students who performed examinations individually. However, students with high individual marks obtained lower marks in the group component and students with low individual marks obtained higher marks in the group component. Group summative assessment marking affects students differently according to their attainment levels. Also Betts et al. (2009) demonstrated that students who were told there was no correction for guessing in multiple choice examinations (MC) performed better than those who were told that there was a correction. When there was no correction for guessing students scored higher. The authors also found that students felt more confident and less anxious in the open-book MC examination.

\subsection{Modes of Assessment}

In this section studies related to different issues regarding modes and functions of assessment are presented. 


\section{Table 3 near here}

\subsubsection{Aim of the studies}

The papers listed in table 3 are related to self-assessment, peer-assessment, continuous assessment, formative assessment and summative assessment. The studies regarding self-assessment focus on students' engagement (Fitzpatrick 2006) and on the improvement of learning (Lew, Alwis and Schmidt 2010). Cassidy (2007) focuses on the ability of the inexperienced students to self-assess and Orsmond and Merry (2013) on tutor feedback in the self-assessment process. The studies whose focus is peerassessment are related to an optimal design of peer-assessment (Berg, Admiraal and Pilot 2006), the presentation of peer assessment method for final marks (Sharp 2006) and students' perceptions of peer assessment (Vickerman 2009; Patton 2012). The study by Langan et al. (2008) aims to know the effects of gender and level of attainment on the triangulation of marks related to self, peer and tutor assessment. In other two studies, the purpose was to get know the effect of continuous summative assessment (Trotter 2006) and continuous assessment on learning process (Isaksson 2008). Other studies explore students' experience of formative assessment (Nestel et al. 2011; Weurlander et al. 2012).

\subsubsection{Methods}

Different research methods were used in the studies listed above. The questionnaire and the interviews were the most used methods for data collection. Focus group, reports, written, oral and practical assessments and spreadsheet software were also used for data collection. In thirteen studies participants were mostly students and in only two both students and teachers participated. There are no studies in which only teachers are participants.

\subsubsection{Key issues arising from the studies}


The findings of the studies related to self-assessment present different issues. Selfassessment is a student-centred approach that engaged learners in the learning process, promoting feedback and developing the students' ability to learn and to self-assess (Orsmond and Merry 2013). Cassidy (2007) suggests that students should do selfassessment activities right in the beginning of their career in higher education, once is appropriate and relevant for them. Other advantages of self-assessment were found by Fitzpatrick (2006). The author explains that students engaging in self-assessment are more articulated and assertive, and that this practice has a significant effect on students' critical thinking skills informing about individual development. Another study (Lew, Alwis and Schmidt 2010) demonstrates that students judged as more competent academically self-assessed with higher accuracy as compared to their less competent peers. This study also shows that the accuracy of the students to self-assess does not improve over time and the students' beliefs about self-assessment do not interfere with the development of self-assessment skills. The studies related to peer assessment show positive aspects of this practice in relation to the learning process. Peer-assessment is appreciated by the students for many reasons; it is useful and effective because it allows interaction between students (Berg, Admiraal and Pilot 2006) and produces formative feedback (Patton 2012). However, the study by Sharp (2006) concludes that students should be assessed individually in group work, but with due recognition of the complexity associated with the process. Although it is a positive experience for students, when teachers are constructing strategies for formative peer assessment, they should be aware of different learning styles in order to develop opportunities for students to learn and assess (Vickerman 2009).

The findings by Langan et al. (2008) explain that tutor assessments were often associated with peer-assessment, rather than with self-warded grades. The studies related to continuous assessment show that the use of continuous summative assessment in the form of tutorial files is positive and the students have the opportunity to learn more about the topic and to articulate their knowledge (Trotter 2006). Furthermore, the study by Isaksson (2008) also shows that continuous assessment provided the perception of the students' progress and facilitates immediate feedback.

The studies related to formative assessment show positive aspects. Formative assessment supports students' learning, influences students' motivation to study and provides awareness of their learning (Weurlander et al. 2012). As formative assessment 
promotes feedback, in the students' perspectives it is essential for their progress and a good experience because it is an effective way to learn (Nestel et al. 2011).

\subsection{Assessment related to a given teaching and learning method}

In this section the studies focused on assessment related to a given teaching and learning method are described.

\section{Table 4 near here}

\subsubsection{Aim of the studies}

The papers listed in table 4 related to different learning, teaching and assessment practices. Some studies aim to know the impact of different practices in students' learning. Klenowski, Askew and Carnell (2006) investigate on how portfolio for learning can be used to develop learning, assessment and professional practices. Jesus and Moreira (2009) explore the use of students' questions as alternative assessment tool and Orr (2010) looks at students' and lectures experiences of group work. Different learning environments are also presented in the studies listed above. Russel et al. (2006) focus on specific features of the online environment and how it enables assessment to contribute to learning. In turn, Burkasaitiene and Tereseviciene (2008) focus on students' perceptions of an experience in a comprehensive learning and assessment system environment. The evaluation of the impact of project led-education on students' learning process and outcomes are the focus of another study (Fernandes, Flores and Lima 2012).

\subsubsection{Methods}

Different research methods were applied in the studies listed above. The questionnaire and the interviews were the most used methods for data collection. Focus group, observation, portfolio, records, self-assessment, problem-based case and a web based master's course were also used for data collection. In six studies, the majority of participants are students and teachers. In the remaining studies, the participants are students. There are no studies in which the participants are only teachers. 


\subsubsection{Key issues arising from the studies}

The findings of the studies related to the impact of given assessment practices on learning reveal different key issues. Klenowski, Askew and Carnell (2006) highlighted the advantages of portfolio in so far as it enables an effective learning and it is seen as an effective form of professional development. Also, Jesus and Moreira (2009) in their study explain that the use of student questions for assessment purposes suggests the improvement of learning. In their opinion the alignment between teaching, learning and alternative modes of assessment based on the stimulation of students' questions occurred. Orr (2010) demonstrates that group assessment provides benefits to learning and it is an effective preparation for life after graduation. However, students and teachers consider that the group work process usually occurred out of university teaching time; that is why teachers need to be aware of students' group dynamics. This study also shows that assessment fairness is also a difficulty; even within student groups, there are opposing ideas about what is fair in an assessment process. Regarding the learning environments and their influence on learning, Russell et al. (2006) demonstrate that new technologies as online environment impact on learning. The development of e-learning brings new opportunities for students to reflect and to innovate as far as assessment practices are concerned. The study by Burksaitiene and Tereseviciene (2008) reveals that the approach of integrating alternative methods of learning and assessment is useful in teaching. The authors also demonstrate that alternative methods such as writing portfolio and project promote benefits for students: they promoted language skills and, for example, portfolios deepened students' satisfaction with the results they achieved. Fernandes, Flores and Lima (2012)'s study on Project Led Education (PLE) pointed to the development of both technical and soft skills and critical thinking, providing the opportunity for students to link the coursework to real situations. Interdisciplinary fostered by PLE was seen an important key feature to the students.

\section{Discussion and conclusion}

The papers analysed show the wide range of research on assessment in higher education so far, as it comprises different dimensions. Not surprisingly, in addition to aspects 
directly related to the assessment process, issues related to teaching and learning process are also identified. The main results of this review show that research over the last 8 years in AEHE, considering assessment, teaching and learning draws attention to different issues: i) assessment methods used in higher education, its effectiveness, fairness, influence on learning and impact on teaching. Aspects related to the assessment methods and their impact on the students' performance are also addressed; ii) modes of assessment in higher education related to self and peer assessment practices and the monitoring of learning taking into consideration formative, continuous and summative assessment; iii) learning and teaching practices and their impact on assessment. The influence of certain learning environments and contexts on student learning and assessment is also discussed.

As far as the topic of assessment methods is concerned, the focus of the majority of the studies is on portfolio assessment, followed by written examinations, oral examinations, group assessment and paper and digital diaries. In regard to the topic related to modes of assessment, it mainly presents studies on self and peer-assessment, followed by formative, continuous and summative assessment. Concerning assessment related to a given teaching and learning method, the studies focused on portfolio assessment, group work assessment, problem solving and project-led education, alternative methods of assessment and online environments. The topic about modes of assessment comprises the majority of the studies, followed by the topic about assessment methods and the topic about assessment related to a given teaching and learning method.

Based on the studies reviewed, the following features were identified: i) the great amount of the studies are from United Kingdom; ii) 2006 was the year in which more papers were published in this topic; iii) the studies are mainly both quantitative and qualitative, although there is a great amount of quantitative studies with the questionnaire as the most widely used method for data collection purposes. As far as qualitative studies are concerned, although they are fewer, the interview and focus group were the most used techniques to collect data; iv) participants were mostly students, although there is a considerable number of studies where both students and teachers participated. There are, however, fewer studies with teachers as participants. It is possible to argue that research in Assessment and Evaluation in Higher Education in the 2006-2013 period, based on the keywords used in the search, shows that most of the studies focus on a variety of methods and practices of assessment. Portfolio assessment, self and peer-assessment are the principal foci of the studies. Moreover topics related to 
the monitoring of learning and alternative contexts of teaching, learning and assessment are also analysed.

In general, research, in the 8 year-period, indicates benefits for students' learning through assessment practices other than the traditional written test. Although there was a difference in the focus and pace of the implementation of the Bologna Process in the European countries, it is possible to discuss the use of alternative or student-centred assessment methods. These methods are consistent with the assumptions underpinning the Bologna Process, and the authors explored the effect of non-traditional assessment practices in higher education in the European context in order to promote alternative environments of learning, teaching and assessment. Also the studies addressed issues related to the role of the student in the assessment process, which may be indicative of a more learner-centred approach that is required by the Bologna Process. However, it is not possible to conclude that the emergence of research on assessment methods centred on learner in higher education in this period is directly or totally related to the Bologna Process. Interestingly, most articles are from UK, where the Bologna Process has had a different impact if compared with other European countries (Furlong 2005; Sweeney 2010). Different issues are implicated in Bologna's implementation in United Kingdom: i) the degree framework system in the UK is different from the rest of Europe, since the norm is the three-year Bachelors and most Masters are one year in duration; and ii) in the UK the use of ECTS system is in some cases avoided (Furlong 2005; Sweeney 2010). Moreover, other issues exist for this to happen: increase fees, reduced mobility, no provision of the Diploma Supplement, etc. (Sweeney 2010). Therefore, there was a difference in the focus and pace of the implementation of the Bologna Process in the European countries and this should be taken into account regarding these findings.

Further research is needed in this field in order to clearly argue for a change in the assessment methods after the implementation of the Bologna process in Higher Education. This would be particularly relevant in the context of large mixed-method studies in different fields of knowledge as there might be differences in the ways in which assessment is carried out and also in which teaching and learning processes occur.

More needs to be done in regard to university teachers as participants as well as students and pedagogical coordinators. In particular issues related to students' monitoring and tutoring need to be explored further. More consistent studies are also necessary in order to investigate the effectiveness and fairness of the so-called alternative or student- 
centred methods as they call for a more active role from the part of the students and a more engaging and time-consuming role from the part of the teacher.

\section{References}

Almond, R. J. 2009. Group assessment: comparing group and individual undergraduate module marks. Assessment \& Evaluation in Higher Education 34 (2): 141-148.

Atkins, M. 1995. What should we be assessing? In Assessment for learning in higher education, ed, P. Knight, 25-34. London: Kogan Page Limited.

Berg van den, I., W. Admiraal, and A. Pilot. 2006. Peer assessment in university teaching: evaluating seven course designs. Assessment \& Evaluation in Higher Education 31 (1): 19-36.

Betts, L., T. J. Elder, J. Hartley, and M. Trueman. 2009. Does correction for guessing reduce students' performance on multiple-choice examinations? Yes? No? Sometimes? Assessment \& Evaluation in Higher Education 34 (1): 1-15.

Biggs, J. 2003. Teaching for Quality Learning at University. Buckingham: SHRE and Open University Press.

Birenbaum, M., and R. Feldman. 1998. Relationships between learning patterns and attitudes towards two assessment formats. Educational Research 40 (1): 90-97.

Black, P., and D. William. 1998. Assessment and classroom learning. Assessment in Education, 5 (1): 7-74.

Boud, D. 1995. Assessment and Learning: contradictory or complementary? In Assessment for learning in higher education, ed, P. Knight, 35-48. London: Kogan Page Limited. 
Boud, D., and N. Falchikov. 2007. Rethinking assessment in higher education: learning for the long term. Routledge: New York.

Brew, C., P. Riley, and C. Walta. 2009. Education students and their teachers: comparing views on participative assessment practices. Assessment \& Evaluation in Higher Education 34 (6): 641-657.

Brinke, D. J., M. A. D. Sluijsmans, and W. M.G. Jochems. 2010. Assessors' approaches to portfolio assessment in Assessment of Prior Learning procedures. Assessment \& Evaluation in Higher Education 35 (1): 55-70.

Brown, G., J. Bull, and M. Pendlebury. 1997. Assessing student learning in higher education. London: Routledge.

Brown, S., and P. Knight. 1994. Assessing learners in higher education. London: Kogan Page.

Brown, S., P. Race, and C. Rust. 1995. Using and experiencing assessment. In Assessment for learning in higher education, ed, P. Knight, 75-86. London: Kogan Page Limited.

Burkšaitienè, N., and M. Teresevičienè. 2008. Integrating alternative learning and assessment in a course of English for law students. Assessment \& Evaluation in Higher Education 33 (2): 155-166.

Cassidy, S. 2007. Assessing 'inexperienced' students' ability to self-assess: exploring links with learning style and academic personal control. Assessment \& Evaluation in Higher Education 32 (3): 313-330.

Dochy, F., and L. McDowell. 1997. Assessment as a tool for learning. Studies in Educational Evaluation, 23(4): 279-298. 
Dochy, F., M. Segers, and D. Sluijsmans. 1999. The use of self-, peer and coassessment in higher education: A review. Studies in Higher Education 24 (3): 331-350.

Drew, S. 2001. Student Perceptions of What Helps Them Learn and Develop. Higher Education, 6 (3): 309-331.

Dysthe, O., and K. Engelsen. 2011. Portfolio practices in higher education in Norway in an international perspective: macro-, meso- and micro-level influences. Assessment \& Evaluation in Higher Education 36 (1): 63-79.

Fernandes, S., M.A. Flores, and R.M. Lima. 2012. Students' views of assessment in project-led engineering education: findings from a case study in Portugal. Assessment \& Evaluation in Higher Education 37 (2): 163-178.

Fitzpatrick, J. 2006. An evaluative case study of the dilemmas experienced in designing a self-assessment strategy for Community Nursing students. Assessment \& Evaluation in Higher Education 31 (1): 37-53.

Flores, M.A., and A.M. Veiga Simão. 2007. Competências desenvolvidas no contexto do Ensino Superior: a perspectiva dos diplomados. In $\mathrm{V}$ Jornadas de Redes de Investigación en Docencia Universitaria. Alicante - Espanha, 4-5 Junho.

Flores, M.A, A.M. Veiga Simão, A. Barros, and D. Pereira. 2014. Perceptions of effectiveness, fairness and feedback of assessment methods: a study in higher education. Studies in Higher Education, DOI:10.1080/03075079.2014.881348.

Furlong, P. 2005. British Higher Education and the Bologna Process: An Interim Assessment. Politics 25 (1): 53-61.

Gibbs, G. 1999. Using assessment strategically to change the way students learn. In Assessment Matters in Higher Education: Choosing and using diverse approaches, eds. 
S. Brown and A. Glasner, 41-53. Buckingham: SHRE and Open University Press.

Gleaves, A., C. Walker, and J. Grey. 2007. Using digital and paper diaries for assessment and learning purposes in higher education: a case of critical reflection or constrained compliance? Assessment \& Evaluation in Higher Education 33 (3): 219231.

Huxham, M., F. Campbell, and J. Westwood. 2012. Oral versus written assessments: a test of student performance and attitudes. Assessment \& Evaluation in Higher Education 37 (1): 125-136.

Isaksson, S. 2008. Assess as you go: the effect of continuous assessment on student learning during a short course in archaeology. Assessment \& Evaluation in Higher Education 33 (1): 1-7.

Jesus, H. P., and A. C. Moreira. 2009. The role of students' questions in aligning teaching, learning and assessment: a case study from undergraduate sciences. Assessment \& Evaluation in Higher Education 34 (2): 193-208.

Klenowski, V., S. Askew, and E. Carnell. 2006. Portfolios for learning, assessment and professional development in higher education. Assessment \& Evaluation in Higher Education 31 (3): 267-286.

Kuisma, R. 2007. Portfolio assessment of an undergraduate group project. Assessment \& Evaluation in Higher Education 32 (5): 557-569.

Langan, A. M., D. M. Shuker, W. R. Cullen, D. Penney, R. F. Preziosi, and C. P. Wheater. 2008. Relationships between student characteristics and self-, peer and tutor evaluations of oral presentations. Assessment \& Evaluation in Higher Education 33 (2): 179-190. 
Lew, M. D. N., W.A.M. Alwis, and H. G. Schmidt. 2010. Accuracy of students' selfassessment and their beliefs about its utility. Assessment \& Evaluation in Higher Education 35 (2): 135-156.

Light, G., and R. Cox. 2003. Learning and Teaching in Higher Education: The Reflective Professional. London: Sage Publications.

Marton, F., and R. Saljo. 1997. Approaches to learning. In The experience of learning. Implications for teaching and studying in higher education, eds. F.Marton, D.Hounsell and N. Entwistle, 39-58. Edinburgh: Scottish Academic Press

Nestel, D., R. Kneebone, C. Nolan, K. Akhtar, and A. Darzi. 2011. Formative assessment of procedural skills: students' responses to the Objective Structured Clinical Examination and the Integrated Performance Procedural Instrument. Assessment \& Evaluation in Higher Education 36 (2): 171-183.

Orr, S. 2010. Collaborating or fighting for the marks? Students' experiences of group work assessment in the creative arts. Assessment \& Evaluation in Higher Education 35 (3): 301-313.

Orsmond, P., and S. Merry. 2013. The importance of self-assessment in students' use of tutors' feedback: a qualitative study of high and non-high achieving biology undergraduates. Assessment \& Evaluation in Higher Education 38 (6): 737-753.

Patton, C. 2012. Some kind of weird, evil experiment': student perceptions of peer assessment. Assessment \& Evaluation in Higher Education 37 (6): 719-731.

Pereira, D., and M.A. Flores. 2012. Percepcões dos estudantes universitários sobre a avaliacao das aprendizagens: um estudo exploratório. Avaliação (Campinas) 17 (2): $529-556$. 
Perrenoud, P. 1999. Avaliação, Da excelência à regulação das aprendizagens: entre duas lógicas. Porto Alegre: ARTMED.

Ramsden, P. 1988. Context and strategy: situational influences on learning. In Learning strategies and learning styles, ed. R. Schmeck, 159-184. New York: Plenum Press.

Russell, J., L. Elton, D. Swinglehurst, and T. Greenhalgh. 2006. Using the online environment in assessment for learning: a case-study of a web-based course in primary care. Assessment \& Evaluation in Higher Education 31 (4): 465-478.

Sambell, K., and, L. McDowell. 1997. The value of self- and peer assessment to the developing lifelong learner. In Improving Student Learning--improving students as learners, ed. C. Rust, 56-66. Oxford, Oxford Centre for Staff and Learning Development).

Sambell, K., L. McDowell, and S. Brown. 1997. But is it fair? An exploratory study of student perceptions of the consequential validity of assessment. Studies in Educational Evaluation 23 (4): 349-371.

Schaaf van der, M. F., and K.M. Stokking. 2008. Developing and validating a design for teacher portfolio assessment. Assessment \& Evaluation in Higher Education 33 (3): 245-262.

Schreier, M. 2012. Qualitative content analysis in practice. London: SAGE Publications.

Scouller, K. 1998. The influence of assessment method on students' learning approaches: multiple choice question examination versus assignment essay. Higher Education 35 (4): 453-472. 
Scouller, K., and M. Prosser. 1994. Students' experiences in studying for multiple choice question examinations. Studies in Higher Education 19 (3): 267-279.

Segers, M., and F. Dochy. 2001. New assessment forms in problem-based learning: the value-added of the students' perspective. Studies in Higher Education 26 (3): 327-343.

Segers, M., D. Gijbels, and M. Thurlings. 2008. The relationship between students' perceptions of portfolio assessment practice and their approaches to learning. Educational Studies, 34 (1): 35 -44.

Sharp, S. 2006. Deriving individual student marks from a tutor's assessment of group work. Assessment \& Evaluation in Higher Education 31 (3): 329-343.

Simão, J., S. Santos, and A. Costa. 2003. Ensino Superior: uma visão para a próxima década. Lisboa: Gradiva.

Sluijsmans, D., F. Dochy, and G. Moerkerke. 1999. Creating a learning environment by using self-, peer- and co-assessment. Learning Environment Research 1 (3): 293-319.

Struyven, K., F. Dochy, and S. Janssens. 2005. Students' perceptions about evaluation and assessment in higher education: a review. Assessment \& Evaluation in Higher Education 30 (4): 325-341.

Sweeney, S. 2010. Bologna Process Responding to the post-2010 challenge. United Kingdom: The Higher Education Academy.

Tang, C. 1992. Perceptions of task demand, strategy attributions and student learning, Research and Development in Higher Education 15:474-481.

Tian, X. 2007. Do assessment methods matter? A sensitivity test. Assessment \& Evaluation in Higher Education 32 (4): 387-401. 
Trotter, E. 2006. Student perceptions of continuous summative assessment. Assessment \& Evaluation in Higher Education 31 (5): 505-521.

Tummons, J. 2010. The assessment of lesson plans in teacher education: a case study in assessment validity and reliability. Assessment \& Evaluation in Higher Education 35 (7): 847-857.

Turner, K., L. Roberts, C. Heal, and L. Wright. 2013. Oral presentation as a form of summative assessment in a master's level PGCE module: the student perspective. Assessment \& Evaluation in Higher Education 38 (6): 662-673.

Vickerman, P. 2009. Student perspectives on formative peer assessment: an attempt to deepen learning? Assessment \& Evaluation in Higher Education 34 (2): 221-230.

Watering, G., D. Gijbels, F. Dochy, and J. Rijt. 2008. Students' assessment preferences, perceptions of assessment and their relationships to study results. Higher Education 56 (6): 645-658.

Webber, K. 2012. The Use of Learner-Centered Assessment in US Colleges and Universities. Research in Higher Education 53 (2): 201-228.

Wen, M., and C. Tsai. 2006. University students' perceptions of and attitudes toward (online) peer assessment. Higher Education 51 (1): 27-44.

Weurlander, M., M. Söderberg, M. Scheja, H. Hult, and A. Wernerson. 2012. Exploring formative assessment as a tool for learning: students' experiences of different methods of formative assessment. Assessment \& Evaluation in Higher Education 37 (6): 747760. 


\section{Documents}

Bologna Declaration. 1999. Joint Declaration of the European Ministers of Education Bologna.

Bucharest Communiqué. 2012. Making the Most of Our Potential: Consolidating the European Higher Education Area.

European Association for Quality Assurance in Higher Education. 2009. Standards and Guidelines for Quality Assurance in the European Higher Education Area. 3rd edition. Helsinki.

Leuven/Louvain-la-Neuve Communiqué. 2009. Communiqué of the Conference of European Ministers Responsible for Higher Education. 